\title{
ХРОНИКА
}

УДК 001(091):548/549

\section{Минералого-геохимические исследования в Пермском университете (1916-2016)}

\section{Р.Г. Ибламинов}

Пермский государственный национальный исследовательский университет, 614990, Пермь, ул. Букирева, 15. E-mail: riaminov@psu.ru (Статья поступила в редакичию 15 августа 2016 г.)

\begin{abstract}
Анализируется история зарождения и развития наук минералого-геохимического цикла в процессе дифференциации и интеграции кафедры минералогии и петрографии Пермского государственного национального исследовательского университета в течение 100 лет её существования. Описано развитие школы минералогии аллювия, наноминералогии. Обсуждается связь геохимического направления с европейской научной школой на раннем этапе. Освещён переход к исследованию малых элементов, благодаря которому в настоящее время создана современная аналитическая база экологической геохимии. Охарактеризованы петрографическое и литологическое направления, обеспечившие базу для восстановления палеотектонических обстановок, существовавших на Западном Урале, а также исследования размещения полезных ископаемых, выполненные на основе минерагеодинамики. Показана концепция минерагеодинамики мировых нефтегазоносных бассейнов, а также методика исследования коллекторов с применением новейших технологий. Уделено внимание роли отдельных личностей в развитии науки.

Ключевые слова: история науки, наноминералогия, геохимия, петрография, литология, геология полезных ископаемых, минерагеодинамика, экогеология, нефтегазовая геология, Пермский университет.
\end{abstract}

DOI: 10.17072/psu.geol.32.80

\section{1. Зарождение минералого-} петрографической школы (1916-1930)

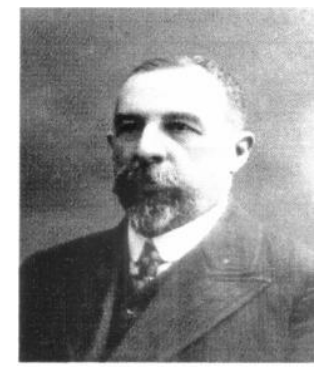

Б.К. Поленов нералого-петрографи-
Начало высшему геологическому и мическому образованию в Пермском крае и на Урале в целом было положено 1 октября 1916 г., когда в г. Перми центре одноименной губернии, было открыто первое на Урале высшее учебное заведение: Пермское отделение Императорского Петроградского университета [40]. На естественном отделении физико-математического факультета была организована кафедра минералогии и геологии. Её возглавил магистр минералогии и геогнозии, статский советник, профессор Борис Константинович Поленов (1859-1923) - выпускник Петербургского университета 1882 г. Он обучался исследованиям микроскопического состава горных пород под руководством проф. А.А. Иностранцева. В 1899 г. защитил диссертацию «Массивные горные породы Витимского плоскогорья» на степень магистра и стал преподавать петрографию. 
Одновременно с профессором Поленовым в Пермь прибыл приват-доцент Петроградского университета, магистр минера-

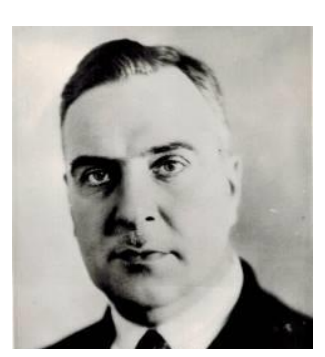

А.А. Полканов логии и геогнозии Александр Алексеевич Полканов (18881963) - будущий академик АН СССР, лауреат Ленинской премии. Первоначально он обучался в Московском университете, где слушал лекции академика В.И. Вернадского, затем перевелся в Петербургский университет, который окончил по специальности «Геология и минералогия» и стажировался у проф. Е.С. Фёдорова. В Пермском университете в течение пяти учебных лет (1916-1921) он занимал должности заведующего кабинетом минералогии и кристаллографии, заведующего кафедрой минералогии, был организатором минералогического музея. В этот период разрухи, революции и гражданской войны А.А. Полканов по заданию Геолкома организовывал экспедиции на Кольский полуостров. Летом 1917 г. он стал первооткрывателем Оленегорского месторождения железных руд [41].

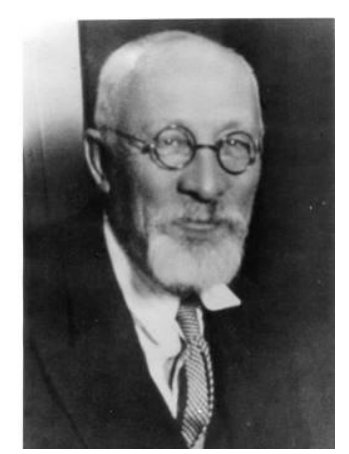

В 1921-1923 гг. обеими кафедрами (геологии и минералогии) руководил Б.К. Поленов, а после его смерти до 1925 г. кафедры возглавлял Павел Иванович Преображенский выпускник Горного П.И. Преображенский института в Петербурге 1890 г. В 1907 1909 гг. он учился в Мюнхене у петрографа Э. Вайншенка. П.И. Преобра-женский (1874-1944) сыграл выдающу-юся роль в раскрытии богатств недр Пермского края. Именно он открыл Верхнекамское месторождение солей и нефтяные месторождения («Второе Баку»).
Дальнейшему развитию геологического образования помешали перестройки в структуре университета в начальный период советской власти.

\section{2. Минералогическое направление}

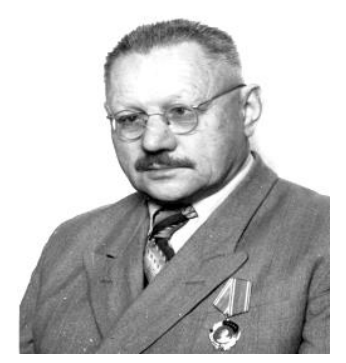

В.К. Воскресенский
Главную роль в становлении минералого-геохимических исследований сыграли повторное открытие в 1931 г. геологического отделения (факультета) и возрождение кафедры минералогии благодаря избранию в 1929 г. её заведующим Владимира Константиновича Воскресенского (18941968). Он возглавлял кафедру в течение 31 года (до 1960).

Обучение студентов планировалось вести по двум специальностям: «Геология» и «Геохимия». Подготовкой геохимиков и развитием геохимической науки занималась кафедра минералогии. Доцент В.К. Воскресенский работал над составлением учебника по генетической минералогии. В 1933 г. под его руководством были выполнены анализы глин района г. Перми.

В 1935 г. для прочтения геохимикам специального курса «Физико-химические методы исследования минералов» на ка-

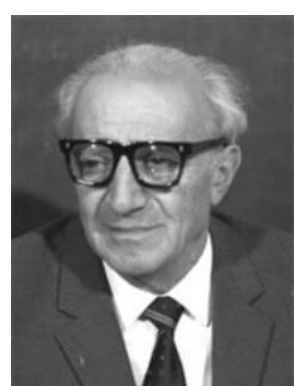

Н.И. Хитаров федру был приглашен инженер Николай Иванович Хитаров (19031985) - впоследствии член-корреспондент АН СССР, зав. Лабораторией магматогенных процессов в ГЕОХИ.

В 1936 г. состоялся первый выпуск геохимиков (23 чел.). Среди них был В.В. Александров, чья дипломная работа переросла в монографию [3] в соавторстве с руководителем Н.А. Игнатьевым и химиком Г.Г. Кобяк. Она посвящена уни- 
кальному минералу волконскоиту - хромовому монтмориллониту.

Кафедра выполняла заказы для промышленных предприятий г. Перми. Так, были проведены исследования алмазов для выяснения причин их поломок в процессе производства. Подобную связь с предприятиями кафедра осуществляет и в настоящее время.

В июле 1937 г. группа делегатов XVII сессии Международного геологического конгресса из 20 иностранных (США, Франция, Германия, Индия) и 19 советских ученых прибыла в Пермь. Коллекция минералогического музея, которая собиралась с 1916 г., вызвала особое восхищение гостей.

В связи с подготовкой к конгрессу зародилось научное направление, связанное с изучением минералогии пермской системы и аллювиальных отложений Прикамья. Так, в статье зав. кафедрой петрографии В.А. Токарева и студентов А.И. Симонова и В.Г. Корякина была описана минералогия террас Камы, приведены описания 26 шлиховых минералов и их микрофотографии [47].

В 1940 г. в статье В.К. Воскресенского, посвященной медистым песчаникам, был описан минерал ванадия фольбортит и указана связь оруденения с углистыми остатками [5].

Великая Отечественная война прервала намечавшийся подъем минералогогеохимического образования и науки. В послевоенные годы изучаются хромовые руды Сарановского месторождения, железные руды Бисерского и Пашийского районов.

В статьях Н.А. Игнатьева (1952) о медно-колчеданных месторождениях в районе Нязепетровска на основе минераграфического исследования руд приводится характеристика минералогии первичных руд, руд зон окисления и вторичного обогащения [17].

В связи с прекращением выпуска геохимиков в 1955 г. была организована объединенная кафедра минералогии и петрографии, которая получила научно- методическое и материальное наследство четырех кафедр: минералогии, петрографии, геохимии и полезных ископаемых.

В связи с выполнением глубокого бурения на территории Пермского края Н.П. Старковым и Г.С. Фон-дер-Флаассом были изучены цирконы кристаллического фундамента востока Русской платформы [43].

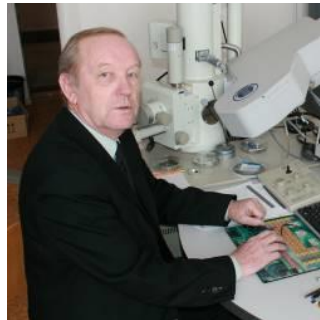

Б.М. Осовеикий
В 1967 г. должность ассистента занял Борис Михайлович Осовецкий, выпускник кафедры 1961 г. Его кандидатская диссертация «Процессы формирования современного аллювия (на трамплином для фундаментальных исследований минералогии аллювия. За время многочисленных полевых экспедиций им была изучена минералогия аллювия крупных рек всей территории бывшего СССР. Он сформировался как минералог экстракласса, им создана известная в России научная школа минералогии аллювия, разработаны теоретические основы миграции и концентрации минералов. Результаты исследований были представлены в 1985 г. в докторской диссертации «Формирование вещественного состава тяжелой фракции аллювиальных осадков» и в многочисленных монографиях [3034]. Под его руководством защитили кандидатские диссертации К.П. Казымов («Условия образования и вещественный состав кайнозойских отложений эрозионно-карстовых депрессий Западного и Северного Урала», 1992) и И.Я. Илалтдинов («Процессы накопления мелкого золота в россыпях зоны пенеплена Южного Урала», 1996).

В середине 90-х гг. активизировались исследования по соляной проблематике, которые вела доцент Н.Е. Молоштанова. Ею была разработана методика минералого-технологического картирования промышленных пластов Верхнекамского месторождения калийных солей [46]. 
В 1997 г. профессору Б.М. Осовецкому было присвоено почетное звание «Заслуженный деятель науки РФ», а в 1998 г. он возглавил кафедру минералогии и петрографии.

В этот период появилась идея о туффизитовых источниках алмазов. Итогом работы доц. И.И. Чайковского в этом направлении явилась докторская диссертация «Петрология и минералогия эксплозивно-грязевого вулканизма ВолгоУральской алмазоносной провинции».

В западной части региона на территориях Коми-Пермяцкого АО и Кировской области в 2003-2005 гг. были проведены полевые экспедиции с обогащением проб аллювия на винтовом сепараторе. Выдающимся результатом деятельности коллектива, возглавляемого проф. Б.М. Осовецким, явилось обнаружение мелких кристаллов алмаза в осадочных породах [29].

Межкафедральный характер носили исследования 2001-2003 гг. по реализации гранта Минобразования «Золото и платиноиды Верхнекамской впадины». Итоги работ были представлены на XIII Международном совещании по геологии россыпей и месторождений кор выветривания, проходившем в Пермском университете в 2005 г.

В 2006 г. кафедра переместилась в новый корпус, где получила несколько научно-исследовательских лабораторий (электронно-зондовых и рентгеноструктурных методов исследования, оптической микроскопии, химических методов исследования и пробоподготовки). В корпусе № 4 разместилась шлифовальная мастерская, а в помещении Естественнонаучного института ПГНИУ - лаборатории термогравиметрических исследований и атомно-абсорбционного анализа.

В период с 2006 по 2011 г. в результате выполнения национального проекта «Образование» было получено уникальное лабораторное оборудование мирового класса. В 2010 г. началось выполнение программы «Национальные исследовательские университеты». При кафедре был создан сектор наноминералогии (руководитель Б.М. Осовецкий). Начали защищать кандидатские диссертации выпускники магистратуры: в марте 2011 г. С.А. Губин на тему «Прогноз коренной алмазоносности территории ВятскоКамской впадины», в 2012 г. под руководством И.И. Чайковского - О.В. Коротченкова («Ефимовское месторождение алмазов: геология, типоморфные минералы и локальный прогноз алмазоносности»).

В 2012 г. сектор наноминералогии кафедры получил Аттестат аккредитации Федеральной службы РФ. В нём указаны такие сферы деятельности как определение минерального, петрографического и химического состава горных пород, шламов и отходов производства, концентраций редких элементов и др. В этом же году начали развиваться идеи о роли наночастиц золота в техногенных месторождениях, представления о наноскульптуре поверхности минералов и необходимости учета ее особенностей при разработке новых методов технологии извлечения золота $[37,54]$. Исследования инновационного характера были связаны с постановкой экспериментов по гравитационному обогащению отходов мокрой магнитной сепарации предприятий Качканарского ГОКа.

Кафедрой поддерживались международные связи с учеными, вузами и фирмами США, Канады, Казахстана, Лаоса, Италии, ФРГ, Норвегии, Японии, Бельгии, Франции, Таджикистана, Белоруссии, Узбекистана. Выполнены (2007-2010) 3 международных договора: с РоссийскоЛаосской компанией «Намикор» по минералогическим исследованиям россыпного касситерита [36], с геологической службой территории Юкон по изучению россыпей золота (Канада) и с фирмой «Сатбор» (Казахстан). Обсуждались вопросы развития сотрудничества с руководителем геологической службы территории Юкон (Канада) Уильямом ЛеБаржем, с сотрудником института геофизики и геомониторинга г. Палермо (Италия) А. Пишиотто. Лаборатории сектора ежегод- 
но посещают студенты Оксфордского университета (Великобритания), прибывающие в ПГНИУ по программе обмена.

В 2013 г. сотрудники кафедры К.П. Казымов и Г.А. Исаева прошли стажировку в Немецком геологическом центре (GFZ, г. Потсдам). В ноябре того же года К.П. Казымов, А.П. Седунова и B.М. Жданов прошли стажировку в университете Людвига-Максимилиана (г. Мюнхен, ФРГ) и ознакомились с современной научной аппаратурой.

В последние годы (2011-2016) разрабатывались проблемы техногенеза благороднометалльных месторождений и платиноносности расслоенных интрузивов (совместно с сотрудниками Геологического исследовательского центра, ФРГ, г. Потсдам и ГЕОХИ РАН, г. Москва). Впервые с помощью электронного микроскопа высокого разрешения была изучена морфология кристаллов алмаза на наноуровне.

Важнейшим итогом работы явилось окончательное оформление трех новых фундаментальных разделов исследований в области минералогии: наноминералогия, изучение вещественного состава нефтяных коллекторов, диагностика структур пород на основе методов рентгеновской компьютерной томографии.

Таким образом, минералогическое направление исследований, заложенное основателями кафедры, всегда связывалось с геологическими особенностями региона, в частности исследование минералогии эвапоритов, терригенных отложений пермской и четвертичной систем, минералогии западного склона Урала. Наиболее весомые результаты были получены при исследовании минералогии аллювия, в результате на кафедре сформировалась соответствующая научная школа. Минералогические исследования прошли путь от макро- и микро- до наноуровня.

\section{3. Геохимическое направление}

Первое десятилетие официального существования геологического факультета (1931 - 1941) прошло «под флагом» становления нового для СССР и мировой науки геохимического направления. Геохимия как наука только зарождалась благодаря исследованиям Э. Резерфорда (1911), Ф.У. Кларка (1908, 1924), В.И. Вернадского «Очерки геохимии» (1927), А.Е. Ферсмана «Геохимия» (19331939 гг.). На химическом факультете Петроградского политехнического института

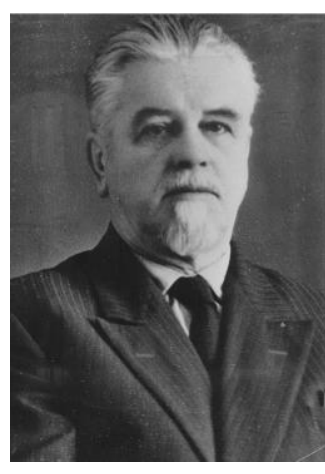

Н.А. Игнатьев организуется геохимическое отделение, которое в 1929 г. окончил Николай Александрович Игнатьев по специальности «Геохимикпетрограф» под руководством академика, основателя химической петрографии Левинсон-Лессинга (1861-1939).

Открытие геохимической специальности в Пермском университете привело к созданию на базе кафедры минералогии ещё трех кафедр: геохимии, петрографии, полезных ископаемых.

Кафедру геохимии организовал Н.А. Игнатьев (1903-1982), который был приглашен на работу в Пермский университет в 1935 г. Благодаря усилиям Н.А. Игнатьева и ассистента В.В. Алексан-

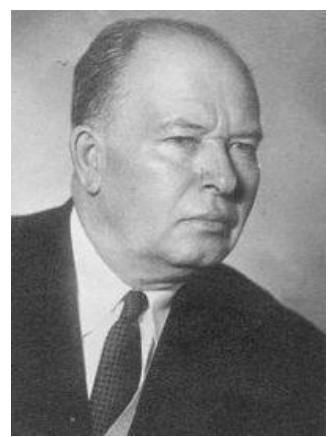

А.А. Сауков дрова кафедра геохимии начала работать в феврале 1936 г. Н.А. Игнатьев преподавал «Введение в геохимию», «Общую геохиМию».

В 1936 г. для чтения спецкурса и руководства дипломными работами был приглашен ст. научный со-

трудник Института геохимии, минералогии и кристаллографии АН СССР им. Ломоносова (г. Москва), кандидат геолого- 
минералогических наук Александр Александрович Сауков, впоследствии членкорреспондент АН СССР, дважды лауреат Сталинских премий и лауреат Ленинской премии за разработку геологогеохимического метода поисков редкометалльных месторождений. После Пермского университета А.А. Сауков продолжил чтение лекций по геохимии в Московском университете и МГРИ. Лекции были изданы в 1940 г.

В 1937 г. в Пермском университете произошло беспрецедентное событие. Здесь были изданы три доклада одного из основоположников геохимии В.М. Гольдшмидта, сделанные им 2 и 3 февраля

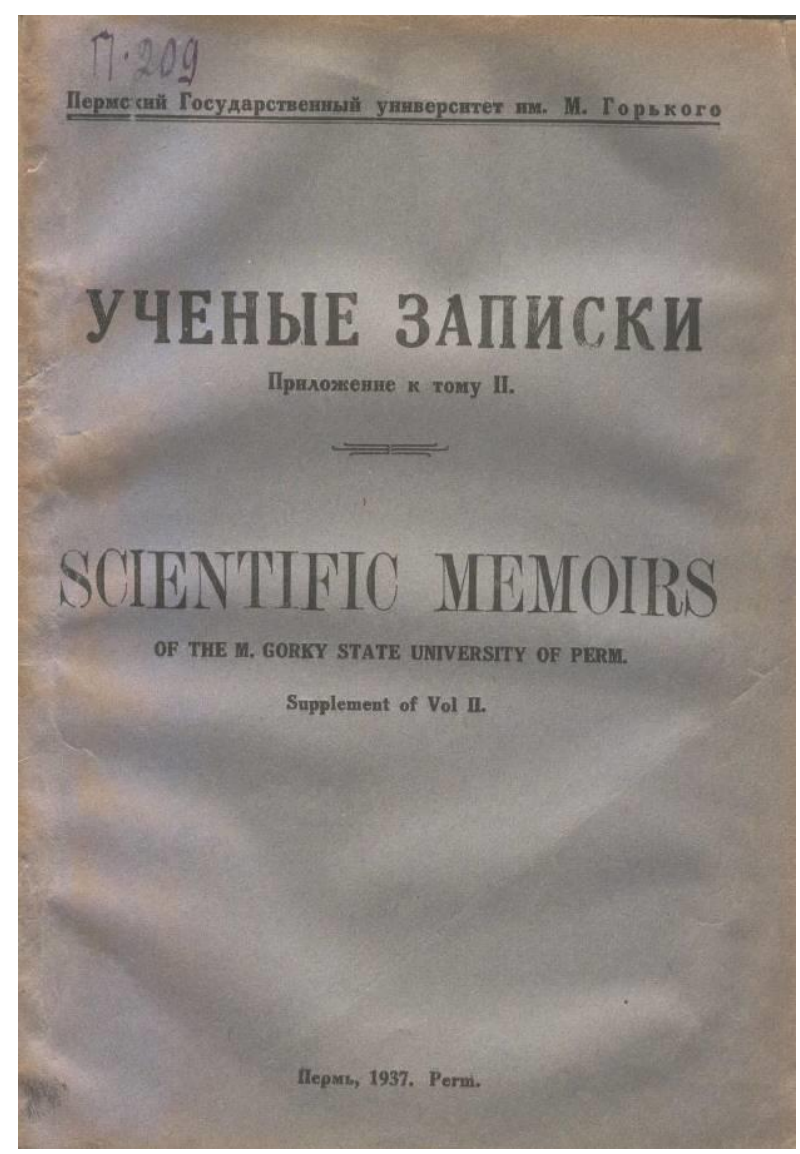

1934 г. в Стокгольме по приглашению Стокгольмской высшей школы и Минералогического общества. В предисловии к изданию Н.А. Игнатьев приводит ответ B.М. Гольдшмидта на просьбу о разрешении перевода: «На Ваш любезный запрос относительно перевода моих «Трех докладов» на русский язык я охотно соглашаюсь и буду рад, что Вы опубликуете статью ..., так как в научном отношении я очень ценю своих коллег в Вашей стране» [6]. Через 78 лет в августе 2015 г. молодые сотрудники кафедры минералогии и петрографии приняли участие в посвященной ему конференции в Праге [55].

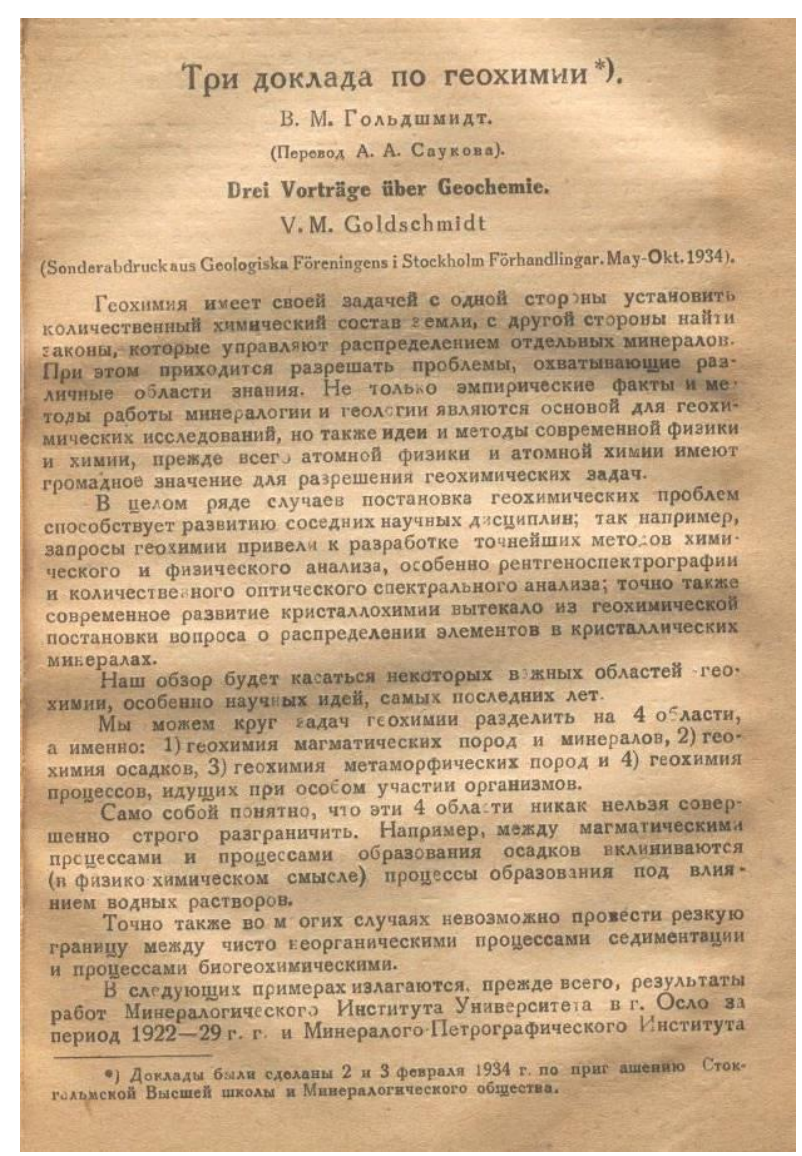

Обложка и титульная страница докладов В.М. Гольдшмидта, опубликованных в Ученых записках Пермского университета в 1937 г.

Дипломные работы студентовгеохимиков отличались широким использованием химических анализов и геохимических показателей А.Е. Ферсмана, таких как параген и энергия кристаллической решетки.
Осенью 1938 г., когда Пермь снова стала административным центром области, на геологический факультет Пермского университета были переведены факультеты Свердловского и Минского университетов, кафедру геохимии возглавил 
и.о. профессора Борис Александрович Гаврусевич (1908-1965). В 1932 г. он окончил аспирантуру АН СССР под руко-

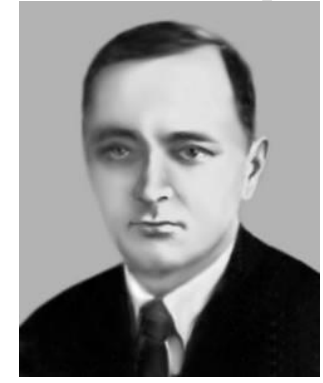

Б.А. Гаврусевич водством А.Е. Ферсмана. Б.А. Гаврусевич автор одного из первых вузовских учебников по геохимии («Основы общей геохимии». М.: Недра, 1968).

В 1942 г. кафедра геохимии была расформирована. Подго-

товка геохимиков была возложена на кафедры минералогии, петрографии и полезных ископаемых.

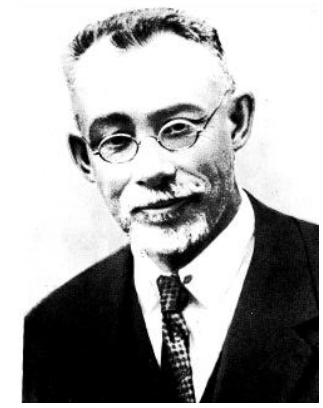

П.Н. Чирвинский
В течение 19431955 гг. на факультете работал один из основателей геохимии и космохимии, проф. Петр Николаевич Чирвинский $\quad(1880$ 1955). За время пребывания в Пермском университете им опубликовано 83 научные статьи, в том числе статьи о кларках [49], о паласситах [51], об ионных и атомных константах псевдоэлементов [50], и монография о среднем химическом составе минералов [52].

Другой геохимик - доц. Ю.М. Абрамович - в 1948 г. опубликовал статью о необходимости изучения геохимии и минералогии редких элементов, в том числе радиоактивных, расклассифицировал формы нахождения химических элементов в земной коре [2]. В марте 1963 г. 100летию со дня рождения В.И. Вернадского была посвящена Международная геохимическая конференция «Химия земной коры», в которой участвовали Н.А. Игнатьев и Ю.М. Абрамович.

Геохимическое направление исследований продолжил Александр Михайлович Кропачев (1927-2015), поступивший на кафедру минералогии в 1953 г. Выпускник-геохимик 1950 г., отработал три года в полевой партии «Дальстроя» на

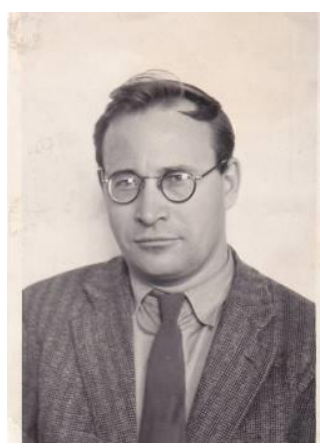

A.M. Кропачев
Чукотке. В 1962 г. им защищена кандидатская диссертация «Малые элементы в нижнепермских осадочных породах Среднего Предуралья и продуктах их выветривания» [19].

В 1966 г. на кафедру был принят Рустем

Гильбрахманович Ибламинов, который тесно сотрудничал с Мойвинской геологосъемочной партией. По поручению её начальника Б.Д. Аблизина он написал главу в производственный отчет о результатах геохимических поисков полезных ископаемых и ряд статей [7]. В 1971 г. в Москве проходил Международный геохимический конгресс, в котором участвовали А.М. Кропачев и Р.Г. Ибламинов. Участие в конгрессе позволило им ознакомиться с современным состоянием науки, отечественными (А.И. Перельман, М.Г. Валяшко и др.) и зарубежными (Д. Шоу, К. Сугавара) учеными.

A.M. Кропачев обобщил результаты массового изучения геохимии малых химических элементов в монографии о внешних и внутренних факторах миграции химических элементов в зоне гипергенеза [20]. В 1975 г. он занял пост заведующего кафедрой минералогии и петрографии. Им была разработана методика исследования динамики процессов литогенеза по малым химическим элементаминдикаторам, которая была поддержана чл.-корр. АН СССР А.С. Хоментовским, ведущим геохимиком-нефтяником проф. С.М. Катченковым, литологом-угольщиком проф. И.В. Пахомовым и многочисленной научной общественностью.

В те годы А.М. Кропачевым и Р.Г. Ибламиновым разрабатывалось новое направление в геохимии: экспериментальное изучение форм нахождения малых элементов в осадках и осадочных породах пермской системы. Начиная с 1973 г. геохимические исследования переключились на изучение современных осадков 
Черноморского шельфа в районе бухты Геленджик. Их инициатором был выпускник университета О.С. Корнев, который с подводным снаряжением опробовал современные осадки [21]. А.М. Кропачевым было продолжено развитие теории геохимических барьеров [23]. Он одним из первых доказал возможность существования геохимических ореолов нефтегазовых месторождений и начал применять литогеохимические методы для их выявления [22], в дальнейшем сосредоточившись в области экологической геохимии[24].

В связи с открытием магистратуры (1993-1996) появились новые дисциплины, такие как «Геохимия изотопов», были составлены контрольно-обучающие компьютерные системы по геохимическим методам поисков. Б.М. Осовецким были выполнены геохимические исследования аллювия [53]. Новую для кафедры научную тематику («Геохимия месторождений нефти и газа»), разрабатывала Т.В. Карасева. В связи с выполнением национальных проектов (2006-2011) на кафедре появилось аналитическое оборудование мирового уровня.

Таким образом, в 30-х гг. кафедры минералого-геохимического цикла оказались лидерами в мировой геохимической науке и образовании. Именно в результате чтения лекций по геохимии в Пермском университете появились первые в СССР учебники А.А. Саукова и Б.А. Гаврусевича. Исследования 50-70-х гг. были основаны на применении спектральных оптических методов, в настоящее время кафедра располагает аналитической аппаратурой, позволяющей решать проблемы современной геохимии.

\section{4. Петрографическое направление}

В 1934 г. на базе кафедры минералогии была организована кафедра петрографии, которую вначале возглавлял заведующий кафедрой динамической геологии Г.А. Максимович. В 1935-1936 гг. кафедрой заведовал доцент В.А. Токарев - выпускник геологоразведочного факультета
Ленинградского горного института (1932), работавший до этого под руководством академика А.Е. Ферсмана начальником минералогического отряда Кольской экспедиции. Появляются публикации на петрографические темы. В 1936 г. Н.А. Игнатьев описал дистеновые породы Карелии и уникальную меланократовую дайковую лампрофировую породу керсантит из Донбасса [15]. Аналогичные породы были выявлены и описаны учеником Игнатьева Ю.В. Шурубором в Вишерском алмазоносном районе в 1960-х гг. Студент кафедры петрографии М.Н. Курзанов описал долериты горы Шиш на 145 км Горнозаводской линии. Он отметил возможность применения породы для каменного литья. Это исследование перекликается с тематикой современных работ кафедры минералогии и петрографии по исследованию пород, пригодных для изготовления базальтового волокна [4].

В течение 1943 - 1953 гг. кафедру петрографии возглавлял проф. П.Н. Чирвинский. Он читал курсы «Петрография кристаллических и осадочных пород», «Петрография СССР» и «История петрографии». Оригинальные лекции сопровождались демонстрацией геологических образцов, собранных им в разных районах мира. Были вычислены кларки магматических пород [49].

В 1947 г. Н.А. Игнатьев дает детальную характеристику петрографии магматических пород (от ультраосновных до кислых) одного из районов Карелии [16]. В другой статье, описывая петрографию и химизм спилитов Урала, он приходит к выводам, отвечающим современным представлениям о подводно-морских условиях их образования из натровой магмы [18].

В 1948 г. окончил обучение и поступил на кафедру петрографии Неон Петрович Старков (1919-1979). С 1947 г. под его руководством началось планомерное изучение петрографии магматических горных пород западного склона Урала. В 1955 г. он защитил кандидатскую диссертацию «Петрографическая характеристика 
левобережья р. Вишеры в междуречье рр. Улс-Вёлс и плато Кваркуш на Урале». Он

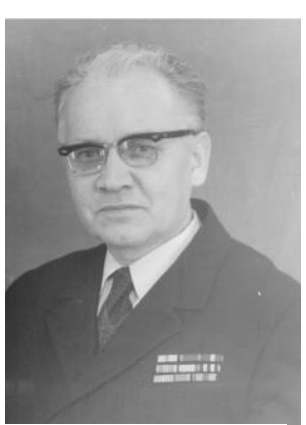

Н.П. Старков впервые на данной территории выделил и изучил магматические породы семейства пикритов [44, 45]. Ему принадлежат открытия Шудьинского месторождения офикальцита и мрамора, Велсовского рудопроявления полиметаллов и Больше-

Сурьинского месторождения магнезитов. Исследованиям магматических пород были посвящены многочисленные курсовые и дипломные работы студентов. В 1960 1975 гг. Н.П. Старков возглавлял кафедру минералогии и петрографии.

В 1993-1996 гг. составлялись программы и лекционные курсы новых петрографических дисциплин, таких как «Петрология», «Геология и петрография Западного Урала», «Современные проблемы геологии», «Методы минералогопетрографических исследований», «Петрохимия».

Итогом комплексных научных исследований Западного Урала явилась защита в 1995 г. кандидатской диссертации ассистентом И.И. Чайковским (руководитель Ф.А. Курбацкая) «Гранитоидный магматизм и геодинамика ЛяпинскоКутимского мегантиклинория Северного Урала».

В 1993-1994 гг. в соответствии с договором о сотрудничестве между университетами Перми и Нанси-2 (Франция) состоялся обмен визитами между пермской и французской делегациями. Проф. Ф.А. Курбацкая и асп. И.И. Чайковский посетили ряд объектов в Вогезах, ознакомились с учебным процессом и лабораториями университета Нанси-2. Профессор К. Гани побывал на кафедре минералогии и петрографии в Пермском университете, где прочел несколько лекций по современным проблемам магматизма. Была организована полевая экскурсия на западный склон Северного Урала, во время ко- торой французский профессор был ознакомлен с гранитоидами р. Мойвы.

С конца 90-х гг. в процессе обобщения материалов творческим коллективом предприятия «Геокарта» и университета (А.М.Зильберман, Р.Г. Ибламинов, Г.В. Лебедев) был выполнен формационный анализ магматических пород и проанализированы палеотектонические обстановки их образования [12].

В 2012-2015 гг. с применением современных оптических, ренгенофлюоресцентных, рентгеноструктурных, термовесовых методов были изучены магматические горные породы Западного Урала [4].

Таким образом, основатели университета, будучи по образованию петрографами, заложили основы рассматриваемого направления на кафедре минералогии. В 30-х гг. были исследованы различные регионы России: Карелия, Мурманская область, Донбасс и др. С конца 40-х гг. основными объектами изучения стали магматические породы Западного Урала.

\section{5. Литологическое направление}

В связи с подготовкой к Международному геологическому конгрессу в 1936 г. была организована экспедиция для изучения верхнепермских отложений ПермскоСарапульского района из числа сотрудников и студентов геологического факультета. В результате возникло научное

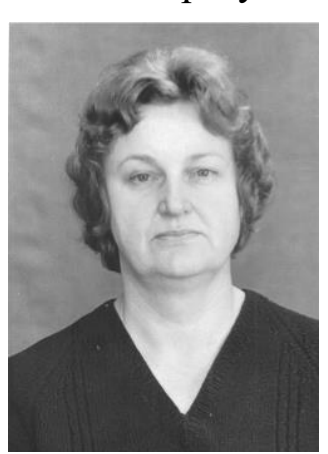

Ф.А. Курбаикая направление, связанное с изучением литологии пермской системы и аллювиальных отложений Прикамья [47].

В 1965 г. в аспирантуру (руководитель Н.А. Игнатьев) поступила начальник тематической партии Пермской геологоразведочной экспедиции Фаина

Алексеевна Курбацкая, проработавшая на производстве 9 лет и специализирующаяся в области литологии. В 1968 г. она 
защитила кандидатскую диссертацию «Корреляция терригенных толщ верхнего докембрия западного склона Среднего Урала и условия их образования». Сложная проблема корреляции «немых» толщ громадной территории была решена ею на основе применения минералоголитологических и геохимических критериев [1]. Эти исследования были развиты Ф.А. Курбацкой в докторской диссертации «Формации и палеотектоника Уральской окраины Восточно-Европейской платформы в позднем докембрии». В ней характеризовалось распределение вендских формаций от Норвегии до Австралийского и Американского континентов. Работа Ф.А. Курбацкой была поддержана академиком В.Е. Хаиным. Материал по литологии Западного Урала был обобщен в атласе микрофотографий горных пород [25]. В 1979 г. Ф.А. Курбацкая возглавила кафедру и руководила ею до 1997 г.

В течение 1993-1996 гг. литологии уделялось особое внимание [38]. Были разработаны новые дисциплины: «Основы теории литогенеза», «Геология дна морей и океанов», «Формационный анализ осадочных отложений», «Обстановки осадконакопления и фации».

Другое направление литологических исследований связано с изучением эвапоритов. Оно посвящено в основном Верхнекамскому месторождению солей и заложено еще П.И. Преображенским, продолжено исследованиями П.Н. Чирвинского, Н.Е. Молоштановой, А.И. Кудряшова, И.И. Чайковского. В настоящее время изучением пород эвапоритовой формации с использованием современной прецизионной аппаратуры занимается Г.А. Исаева. Она на основании изучения терригенного материала восстанавливает условия седиментогенеза и диагенеза коллизионного пермского Предуральского и спредингового юрского Евроазиатского бассейнов.

Ассистент кафедры А.Н. Багаев в 2015 г. защитил кандидатскую диссертацию «Модель седиментации эмссконижнефранских отложений в зоне сочле- нения восточной окраины Русской плиты, Предуральского краевого прогиба и Западно-Уральской зоны складчатости (Пермский край)» (руководитель Р.Г. Ибламинов).

Как уже отмечалось, крупные региональные исследования литологии аллювия были выполнены Б.М. Осовецким и его учениками.

Таким образом, литологические исследования кафедры охватывают весь разрез осадочных пород региона - от рифея до четвертичных, наиболее детально проработаны вопросы литологии позднего докембрия, пермской и четвертичной систем.

\section{7. Геология полезных ископаемых, минерагеодинамика}

Научное направление, связанное с изучением месторождений полезных ископаемых, всегда было одним из важнейших в российской геологии. На кафедре минералогии его заложили отцыоснователи открытием месторождений в различных регионах России и прежде всего в Пермском крае. Открытие месторождений калийно-магниевых солей и нефти обеспечило существование и развитие экономики региона на долгие годы.

В середине 30-х гг. на кафедре минералогии В.К. Воскресенским была разработана новая учебная дисциплина - «Учение о месторождениях рудных и неруд-

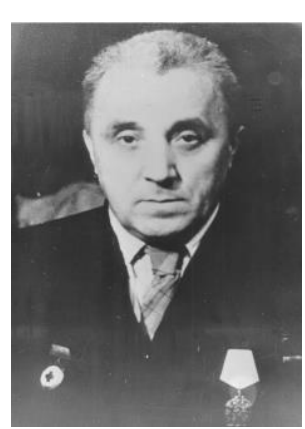

Ю.М. Абрамович ных полезных ископаемых».

В 40-х гг. на базе кафедры минералогии была создана кафедра полезных ископаемых, которую возглавил доцент Юрий Михайлович Абрамович (18991986). В 1930-1932 гг. он прошел аспирантскую подго-товку в Институте геологии АН УССР в г. Киеве, а в 1938 г. был переведен в Пермский университет из Свердловского университета. 
В связи с послевоенным восстановлением народного хозяйства страны главными объектами исследований становятся стройматериалы и руды. Изучаются хромовые руды Сарановского месторождения, железные руды Бисерского и Пашийского районов, месторождения кирпичных и огнеупорных глин. П.Н. Чирвинский посвятил одну из статей физикомеханическим свойствам соляных пород Первого Соликамского рудника и дал рекомендации по изменению размера целиков при добыче солей (1948). Итоги пяти послевоенных лет были подведены на научной конференции 1950 г., на которой П.Н. Чирвинский доложил о выполнении исследований по теме «Полезные ископаемые Урала и их использование». Н.А. Игнатьев (1952) опубликовал статью о медно-колчеданных месторождениях района Нязепетровска [17]. П.Н. Чирвинский в своей публикации провел аналогию между миграцией нефти и рудоносных растворов (1952). А.М. Кропачев и Б.С. Лунев описали месторождения гравия, песка и глин Пермской области (1959) [28]. В начале 60-х гг. в основном из числа студентов-геологов Н.П. Старковым была организована экспедиция по опоискованию Кирсинского месторождения отбеливающих глин в Кировской области [42].

Научная работа ст. преподавателя А.Я. Литвинова была связана с исследованием Оленегорского железорудного месторождения, которое открыл и изучал в начале века первый заведующий кафедрой минералогии А.А. Полканов. А.Я. Литвинов отстаивал идею метасоматического образования богатых руд месторождения [27].

В 1972-1975 гг. А.И. Кудряшов, будучи ассистентом кафедры минералогии и петрографии ПГУ, приступил к исследованию Верхнекамского месторождения солей под руководством зав. кафедрой поисков и разведки В.Ф. Мягкова. В 1977 г. он защитил кандидатскую диссертацию «Геолого-геохимический анализ строения Верхнекамского калийного месторожде- ния и его районирование в целях эксплуатации».

В 1973 г. Пермскому университету совместно со Свердловским горным институтом было поручено составление инструктивно-методических руководств по эксплуатационной разведке и геологическому обслуживанию на горнодобывающих предприятиях Минчермета СССР. Ассистентом Р.Г. Ибламиновым были изучены Качканарское, Первоуральское и Кусинское месторождения титаномагнетитовых руд, Сарановское и Кемпирсайское - хромовых руд, Бакальское - сидеритов и бурых железняков, а также месторождения Атасуйской группы Казахстана и Дашкесанское скарново-магнетитовое месторождение в Азербайджане. Исследования способствовали улучшению преподавания дисциплины «Геология полезных ископаемых» и написанию Р.Г. Ибламиновым диссертации «Исследование распределения геологических параметров рудных залежей титаномагнетитовых месторождений Урала в связи с вопросами разведки» (научный руководитель В.Ф. Мягков). Работа была поддержана академиком В.И. Смирновым и весной 1977 г. защищена в Москве.

Результаты исследований Р.Г. Ибламинова и Г.В. Лебедева месторождений скарново-магнетитовых руд, а также дунитов и флюсовых известняков Нижнетагильского металлургического комбината были опубликованы в виде книгиинструкции по геологическому обслуживанию [8], которая действует до настоящего времени. Позже для месторождений Кемпирсайской группы ими была разработана инструкция по геологическому обслуживанию шахт и карьеров Донского ГОКа (Казахстан).

В 1993-1996 гг. для подготовки магистров составлялись курсы новых дисциплин: «Современные проблемы геологии», «Геология месторождений драгоценных камней», «Основы металлогении», «Рынки минерального сырья», «Экономика минерального сырья и правовые основы недропользования», «Ком- 
плексирование геофизических методов (геологические основы)», «Основы теории рудообразования (синергетика геологических систем и процессов)».

С начала 90-х гг. в университете начали выполняться комплексные исследования геологии Пермского Прикамья. Под руководством профессора Б.М. Осовецкого было оценено состояние природных условий и ресурсов Пермской области (1990). Результатом развития подобных исследований явилась монография Р.Г. Ибламинова и Г.В. Лебедева о геологии и полезных ископаемых Коми-Пермяцкого автономного округа [9].

Фундаментальные петрографические и литологические исследования ученых кафедры заложили теоретическую основу для выполнения минерагенических исследований. В 1993 - 1994 гг. по заказу Мойвинской партии Пермской геологосъёмочной экспедиции была выполнена прогнозно-металлогеническая оценка южной части Ляпинско-Кутимского мегантиклинория и составлена геодинамическая модель его развития как основа минерагенических построений (Р.Г. Ибламинов, Г.В. Лебедев, Ф.А. Курбацкая). В 1995-2000 гг. для выполнения темы «Научные основы минерагенических исследований Центрально-Уральского поднятия и Западно-Уральской зоны складчатости в пределах Северного и Среднего Урала» был создан творческий коллектив ученых кафедры минералогии и петрографии (Ф.А. Курбацкая, Р.Г. Ибламинов), кафедры поисков и разведки (Г.В. Лебедев, А.С. Сунцев, В.И. Набиуллин) и сотрудников предприятия «Геокарта» (А.М. Зильберман, Г.О. Пунтусова и др.). В результате на геолого-формационной основе был составлен комплект металлогенических карт масштаба 1:200 000 и приложения к ним.

Одновременно под руководством Ф.А. Курбацкой выполнялись прогнозноревизионные исследования алмазоносности территории Пермской области. Были установлены критерии прогнозирования залежей алмазов в регионе, прорабатыва- лась идея флюидизатно-эксплозивных пород.

Завершающим этапом характеризуемых исследований (1999-2001) явилось создание для Пермгеолкома региональной минерагенической базы данных и автоматизированного рабочего места геолога [26].

Р.Г. Ибламиновым для минерагении, базирующейся на тектонике плит, был предложен термин «минерагеодинамика» [10]. В 2002 г. он представил докторскую диссертацию «Минерагеодинамические основы прогнозирования месторождений твердых полезных ископаемых», которая была поддержана академиком В.А. Коротеевым.

Для обучения в магистратуре был введен профиль «Экономическая геология» с преподаванием дисциплин «Мировая экономика минерального сырья», «Геологопромышленные типы месторождений», «Геолого-экономическая оценка месторождений» и др., было опубликовано учебное пособие с грифом УМО «Экономика минерального сырья» [11].

В 80-х гг. продолжила исследования и защитила кандидатскую диссертацию «Геологические условия осадконакопления сильвинитов Верхнекамского месторождения» доцент Н.Е. Молоштанова. В 1999 г. она приняла участие в работе Международной конференции по проблемам изучения солей, которая состоялась в г. Минске.

К исследованиям Верхнекамского месторождения присоединился И.И. Чайковский, который разрабатывает вопросы генезиса, тектоники, вещественного состава соляных пород. В мае 2013 г. Н.Е. Молоштанова приняла участие в заседании экспертного совета при президенте Узбекистана И.А. Каримове в г. Ташкенте по вопросу о способе разработки Тюбегатанского месторождения солей.

В 2002 г. приступил к работе на кафедре Б.В. Перевозчиков - крупный специалист по гипербазитовым массивам и месторождениям хромовых руд Урала и о. Кубы. В 2005 г. на хоздоговорной основе 
под его руководством были проведены полевые работы на массиве Сыум-Кеу, по итогам которых ассистент А.В. Плотников, обучаясь в аспирантуре, защитил в 2009 г. кандидатскую диссертацию «Анализ перспектив хромитоносности массива Сыум-Кеу (Полярный Урал)».

В том же году защитили кандидатские диссертации А.Г. Попов по минерагении Пермского края (научный руководитель Ф.А. Курбацкая), а в 2011 г. А.К. Алванян по месторождениям общераспространенных полезных ископаемых Пермского края (научный руководитель Р.Г. Ибламинов).

С 10 по 17 мая 2012 г. сотрудниками кафедры была подготовлена и осуществлена программа визита профессора Кейптаунского университета Дэвида Рейда (ЮАР) и сотрудника Немецкого аналитического центра (г. Потсдам, ФРГ) Ильи Векслера в рамках программы приглашения в ПГНИУ ведущих ученых мировых научных центров. Дэвидом Рейдом был прочитан цикл лекций о геологических особенностях строения и платиноидах комплекса Бушвельд, современных методах аналитических исследований, проведены научные семинары. Для прибывших ученых была организована автомобильная геологическая экскурсия по востоку Пермского края с посещением Сарановского месторождения хромовых руд.

С 18 мая по 5 июня 2012 г. ПГНИУ посетил сотрудник университета Western Kentucky University (США) Рональд Галлагер, который выступил с докладом на конференции «Геология и полезные ископаемые Западного Урала».

С 2014 г. на кафедре минералогии и петрографии разрабатывается проект, поддержанный Российским научным фондом, «Роль электрохимических процессов и жидкостной несмесимости в образовании стратиформных месторождений хромита, титаномагнетита и платиноидов» (руководитель проф. И.В. Векслер). В проекте участвуют магистранты и молодые преподаватели кафедры Е.M. Томилина и А.П. Седунова, а также сотрудники
Геологического исследовательского центра г. Потсдама (ФРГ) и института ГЕОХИ РАН (Москва). Ассистент А.П. Седунова работает над диссертацией «Структурно-минералогическое изучение платиноносных хромититовых слоев интрузивного комплекса Бушвельд (ЮАР)». Летом 2015 г. она участвовала в Международной конференции геохимического общества, посвященной В.М. Гольдшмидту, которая проходила в Праге [55].

Работу по алмазной тематике продолжил старший преподаватель Ю.Г. Пактовский - геолог-производственник, специалист по поискам и разведке месторождений алмазов, участник открытия новых алмазоносных россыпей в Красновишерском районе Пермского края.

Начиная с 2011 г. кафедра участвует в изучении золотоносности углеродистых толщ западного склона Урала, в 2016 г. осуществлена полевая экспедиция для уточнения разреза углеродистых толщ и золотоносности их кор выветривания.

Продолжаются исследования традиционного объекта, которым является Сарановское месторождение хромовых руд. Изучаются новые участки месторождения и валунчатые россыпи. Аспирант А.Ю. Пузик исследует проблемы геологических условий формирования КваркушскоКаменногорского мегантиклинория и места в них хромового оруденения.

Важным обобщением минерагеодинамических исследований явилась книга Р.Г. Ибламинова «Минерагения (основы минерагеодинамики)» [14].

\section{8. Геоэкология}

В 90-х гг. ХХ в. в мире активизировался интерес к геоэкологии. Зав. кафедрой Б.М. Осовецкий участвовал в семинаре «Экологические проблемы городов мира» (Оксфорд, 1993), в конгрессе ИНКВА (Берлин, 1995), в Международном геологическом конгрессе (Пекин, 1996). В рамках региональной научно-технической программы (НТП) «Экология Западного Урала» (1991-1999) велись работы по 
изучению состояния геологической среды городов Прикамья (Б.М. Осовецкий, А.М. Кропачев, Р.Г. Ибламинов). Большой вклад в развитие экологического направления внес проф. А.М. Кропачев. Важное прикладное значение имеют его разработки по созданию искусственных геохимических барьеров с целью охраны окружающей среды, им было получено 10 патентов.

Е.А. Меньшикова под руководством Б.М. Осовецкого защитила кандидатскую диссертацию «Процессы формирования техногенно-аллювиальных осадков рек Урала» (1998). Позже ими совместно было выполнено несколько работ по грантам и опубликована монография [35]. Е.А. Меньшикова руководила грантами «Исследование процессов современного аллювиального седиментогенеза» (20082009), «Разработка концепции экологически безопасного освоения Верхнекамского месторождения солей» (2009-2014).

Работы инновационного характера были связаны с разработкой технологических схем утилизации ценных продуктов, присутствующих в отходах производства (Качканарский ГОК, ООО «Северчернь», г. Вологда). Началось выполнение темы по созданию технологии переработки отходов хромовых руд, предложены технологии комплексного использования отвалов Кизеловского угольного бассейна.

\section{9. Геология и геохимия месторождений нефти и газа}

Нефтегазовое направление исследований на кафедре минералогии было заложено ещё в период заведования ею П.И. Преображенским. Однако непосредственно на кафедре оно было инициировано Татьяной Владимировной Карасевой заместителем директора по научной работе ин-та КамНИИКИГС, которая по совместительству временно начала преподавать на кафедре в 2000-х гг. Под её руководством ассистент кафедры минералогии и петрографии К.А. Мещеряков в 2011 г. защитил кандидатскую диссертацию
«Особенности формирования нефтегазоносности триасовых отложений севера Западной Сибири». На кафедре начала преподаваться дисциплина «Нефтегазовая литология», было организовано дополнительное образование по программе «Менеджер нефтегазового бизнеса».

Нефтегазовое направление развивается в тесном сотрудничестве с учеными других кафедр и организаций. Среди них нефтяники (Т.В. Карасева, Ю.В. Парфенова), геофизики (В.А. Гершанок, М.С. Чадаев) $[13,39,48]$.

В 2011-2013 гг. окончательно оформился новый фундаментальный раздел исследований: изучение вещественного состава нефтяных коллекторов. Разработана оригинальная технология изучения пористости коллекторов с помощью рентгеновской томографии.

Нефтегазовая литология развивается как в исследовательском, так и учебном процессах. Магистерская программа «Прикладная литология» включает такие дисциплины, как «Минерагеодинамика нефтегазоносных бассейнов мира», «Нефтегазовая литология», «Нефтегазопромысловая геология».

\section{Заключение}

Современное общее направление научных исследований кафедры «Глобальные закономерности размещения минеральных ресурсов и региональные аспекты их прогнозирования с использованием наноминералогических технологий» в качестве составных частей включает исследования в области металлических и неметаллических полезных ископаемых, геологии месторождений нефти, газа и конденсата. Работы базируются на комплексном изучении геохимии, минералогии, петрографии, литологии полезных ископаемых и вмещающих горных пород с применением современных прецизионных методов исследования. Кафедра стала одним из мировых центров по проблемам наноминералогии. 
Результаты работ ученых кафедры систематически представляются и обсуждаются на региональных, всероссийских и международных конференциях, симпозиумах и конгрессах. Все это позволяет поддерживать высокий уровень преподавания учебных дисциплин и разрабатывать новые. Кафедра обладает высоким научным потенциалом, при ней существует аспирантура. Дальнейшее развитие кафедры минералогии и петрографии обеспечат её молодые кадры.

\section{Библиографический список}

1. Аблизин Б.Д., Клюжина М.Л., Курбаикая Ф.А., Курбаикий А.М. Верхний рифей и венд западного склона Среднего Урала. М.: Наука, 1982.140 с.

2. Абрамович Ю.М. Формы нахождения редких элементов в земной коре // Учен. зап. Перм. гос. ун-та. 1956. Т. 10, вып. 2. С. 179-184.

3. Александров В.В., Игнатьев Н.А., Кобяк Г.Г. Волконскоит Прикамья // Учен. зап. Молотов. ун-та. 1941. Т.4, вып. 3.77 с.

4. Блинов С.М., Ваганов С.С., Векслер И.В., Ергалиев Р.Т., Ждакаев В.И., Золотарёв Л.Р., Ибламинов Р.Г., Исаева Г.А., Казымов К.П., Крутик И.А., Манькова Т.В., Меньшикова Е.А., Осовеикий Б.М., Перевозчиков Б.В., Пишиотта А., Седунова А.П., Суслов С.Б. Минерально-сырьевая база Пермского края для производства базальтового волокна / под ред. Р.Г. Ибламинова / Издат. центр ПГНИУ. Пермь, 2015. $369 \mathrm{c}$.

5. Воскресенский В.К. К минералогии медистых песчаников // Учен. зап. Пермского гос. ун-та. 1940. Т. 3, вып. 3. С. 73-78.

6. Гольдмиидт B.M. Три доклада по геохимии // Учен. зап. Перм. ун-та. Приложение к т. II. $1937.42 \mathrm{c}$.

7. Ибламинов Р.Г., Кропачев А.М., Аблизин Б.Д. Геохимия малых (акцессорных) элементов донных отложений мелких речек Северного Урала // Аллювий. Пермь, 1973. Вып. 2. С. 40-45. (Учен. зап. Перм. ун-та. № 266).

8. Ибламинов Р.Г., Лебедев Г.В. Инструкция по геологическому обслуживанию горнодобывающих предприятий Нижнетагильского металлургического комбината / Перм. гос. ун-т. Пермь, 1989. 181 с.
9. Ибламинов Р.Г., Лебедев Г.В. Геология и полезные ископаемые Коми-Пермяцкого автономного округа. Кудымкар: КомиПермяцкое кн. изд-во, 1995. $136 \mathrm{c.}$

10. Ибламинов Р.Г. Основы минерагеодинамики. Пермь: Изд-во Пермского ун-та, 2001. $220 \mathrm{c}$.

11. Ибламинов Р.Г. Экономика минерального сырья: учеб. пособие / Перм. гос. ун-т. Пермь, 2004. 308 с.

12. Ибламинов Р.Г., Лебедев Р.Г. Вулканические комплексы магматических формаций западного склона Среднего и Северного Урала // Литосфера. 2006. № 1. С. 76-90.

13. Ибламинов Р.Г. Основы геологии и геохимии нефти и газа: учеб. пособие / Перм. гос. ун-т. Пермь, 2007. 256 с.

14. Ибламинов Р.Г. Минерагения (основы минерагеодинамики): учеб. пособие / Перм. гос. нац. исслед. ун-т. Пермь, 2015. 322 с.

15. Игнатьев Н.A. Керсантитовые дайки из шахты Артем Власовского рудника Донецкого бассейна // Учен. зап. Перм. унта. 1936. Т. 2, вып. 3 (юбилейный). С. $237-$ 259.

16. Игнатьев Н.А. Геолого-петрографический очерк Пулонгских озер в Карело-Финской ССР // Учен. зап. Перм. ун-та. 1947. Т.4, вып. 4. С. 123-140.

17. Игнатьев Н.А. Руды медных месторождений Нязепетровского района // Учен. зап. Молотов. ун-та. 1952. Т.7, вып.1. С. 39-55.

18. Игнатьев Н.А. Спилиты Нязепетровского района // Учен. зап. Молотов. ун-та. 1952. Т.7, вып. 1. С. 61-67.

19. Кропачев А.М. Геохимическое унаследование нижнепермских морских бассейнов Предуральского прогиба // Докл. АН СССР. 1964. Т. 159, № 1. С. 111-113.

20. Кропачев А.М. Факторы миграции и осаждения малых (акцессорных) элементов в зоне гипергенеза. Пермь, 1973. 155 с.

21. Кропачев А.М., Корнев О.С., Ибламинов P.Г. Опыт исследования формы нахождения малых элементов в современных морских осадках // Комплексное применение геологических методов исследования морского дна. Южно-Сахалинск, 1978. С. 57-63.

22. Кропачев А.М. Генетическая информация на уровне минералов в ореолах рассеяния углеводородных залежей // Новые идеи в 
генетической минералогии. Л., 1983. С. 87-89.

23. Кропачев А.М. Геохимические барьеры литогенеза и формирование месторождений полезных ископаемых / Перм. гос. унт. Пермь, 1983. 97 с. Деп. в ВИНИТИ 18 апр. 1983, № 2014.

24. Кропачев А.М. Экологическая геохимия: положение в системе естественных наук // Экология фундаментальная и прикладная: Проблемы урбанизации: матер. Междунар. науч.-практ. конф. Екатеринбург, 2005. C. 170.

25. Курбаикая Ф.А., Рыбальченко Т.М., Савченко С.В. Атлас микрофотографий терригенных и эксплозивно-инъекционных пород западного склона Северного и Среднего Урала. Пермь, 2001. 124 с.

26. Лебедев Г.В., Ибламинов Р.Г., Ибламинова Н.Ф. Региональная минерагеническая база данных как автоматизированное рабочее место геолога (АРМГ) // Прикладная геохимия: сб. ст. М., 2004. Вып. 5: Компьютерные технологии. С. 401-413.

27. Литвинов А.Я. Скарнирование и амфиболизация во вмещающей толще Оленегорского месторождения железистых кварцитов // Сов. геология. 1970. № 5. С. 55-68.

28. Лунев Б.С., Кропачев А.М. Месторождения гравия, песка и глин в Пермской области. Пермь: Перм. кн. изд-во, 1959. 148 с.

29. Морозов Г.Г., Осовеикий Б.М., Накарякова И.Р., Рыбальченко А.Я, Шафрановский Ю.И., Курбаикая Ф.А.,Казымов К.П., Илалтдинов И.Я. Первые находки алмазов на территории платформенной части Пермского края // Геология и полезные ископаемые Западного Урала. Пермь, 2006. C. 6-8.

30. Осовецкий Б.М. Тяжелая фракция аллювия. Иркутск: Изд-во Иркут. ун-та, 1986. $259 \mathrm{c}$.

31. Осовецкий Б.М. Падение минералов в тяжелых жидкостях: Новые методы исслед. Иркутск: Изд-во Иркут. ун-та, 1992. 138 с.

32. Осовеикий Б.М. Дробная гранулометрия аллювия / Перм. гос. ун-т. Пермь, 1993. $343 \mathrm{c}$.

33. Осовеикий Б.М. Типохимизм шлиховых минералов: справочник / Перм. гос. ун-т. Пермь, 2001. 244 с.

34. Осовецкий Б.М. Минералогия мезокайнозоя Прикамья. Избранные труды. Пермь: Изд-во ПГУ, ПСИ, ПССГК, 2004. 292 с.

35. Осовецикий Б.М., Меньшикова Е.А. При- родно-техногенные осадки. Пермь: Изд-во Перм. ун-та, 2006. 208 с.

36. Осовецикий Б.М., Казымов К.П., Бунтин Суваннудом. Морфология и химизм касситерита из элювиальной россыпи рудного поля Боненг (ЛНДР) // Проблемы минералогии, петрографии и металлогении. Научные чтения памяти П. Н. Чирвинского. Пермь, 2011. Вып. 14. С. 76-88.

37. Осовецкий Б.М. Наноскульптура поверхности золота / Перм. гос. ун-т. Пермь, 2012. $231 \mathrm{c}$.

38. Осовецкий Б.М., Молоштанова Н.Е. Литология (классификация, методы исследования, описание осадочных пород): учеб. пособие / Перм. гос. ун-т. Пермь, 2012. $158 \mathrm{c}$.

39. Парфенова Ю.В. Нефтегазопромысловая геология: учеб. пособие / под ред. Р.Г. Ибламинова; Перм. гос. ун-т. Пермь, 2010. $273 \mathrm{c}$.

40. Пермский государственный университет имени А.М. Горького: исторический очерк 1916-1966. Пермь: Перм. кн. изд-во, 1966. $294 \mathrm{c}$.

41. Полканов А.А. Предварительный отчет о геологических исследованиях вдоль Мурманской железной дороги на участке от города Мурманска до станции Оленья // Изв. Геол. комитета. 1918. Т. 37, № 7-8. С. 589-599.

42. Старков Н.П. Кирсинские отбеливающие глины // Экспресс-информации ЦБТИ Пермского совнархоза. Хим. промышленность. 1960. № 22. С. 1-4.

43. Старков Н.П., Фон-дер-Флаасс Г.С. Формы зерен акцессорного циркона в породах кристаллического фундамента востока Русской платформы // Генезис минеральных индивидов и агрегатов, онтогения минералов. М., 1966. С. 284-290.

44. Старков Н.П. Минералогия пикритов западного склона Урала // Проблемы петрологии Урала. Тр. института геологии и геохимии УНЦ АН СССР. Свердловск, 1973. Вып.100. С. 53-69.

45. Старков Н.П., Фоминых В.Г., Зильберман A.M. Диабазовые и габбродиабазовые формации западного склона Урала // Петрология и металлогения базитов. М.: Наука, 1973. С. 166-168.

46. Тетерина Н.Н., Алиферова С.Н., Апполонов В.Н., Молоштанова Н.Е. Влияние несоляных минералов на технологические свойства руды и продукты обогащения 
Верхнекамского месторождения солей // Обогащение руд. 2005. № 1. С. 16-19.

47. Токарев В. А., Симонов А. И. К материалам по петрографии четвертичных отложений Пермского района (В.-Муллинские пески) // Учен. зап. Перм. гос. ун-та. 1936. Т. 2, вып. 2. С. 17-36.

48. Чадаев М.С., Ибламинов Р.Г., Гершанок Л.А., Гершанок В.А., Простолупов Г.В. Геологические структуры западного склона Северного и Среднего Урала по данным гравиметрии и магнитометрии // Литосфера. 2011. №6. С. 134-140.

49. Чирвинский П.Н. Кларки магматических пород щитов и геосинклиналей // Академику Дмитрию Степановичу Белянкину к семидесятилетию со дня рождения и сорокапятилетию научной деятельности. М.; Л.: Изд-во АН СССР, 1946. С. 178-183.

50. Чирвинский П.Н. Ионные и атомные константы псевдоэлементов. Учен. зап. Перм. гос. ун-та. 1948. Т. 4, вып. 4. С. 165-179.

51. Чирвинский П.Н. Палласиты, их количественный химико-минералогический со- став и количественная роль среди других групп метеоритов // Метеоритика: сб. статей /под ред. В.Г. Фесенкова. М.;Л.: Издво АН СССР, 1949. Вып. 6. С. 54-63.

52. Чирвинский П.Н. Средний химический состав главных минералов изверженных, метаморфических и осадочных пород/ Харьков. гос. ун-т. Харьков, 1953. 96 с.

53. Osovetskiy B.M. Geochemistry of fluvial sediment heavy fraction // Geochemistry 2004: the 6th International Conference of Geochemistry: Abstracts. Alexandria, 2004. P. 155-156.

54. Osovetsky B.M. Aggregation of Nanogold Particles in the Environment // Natural Resources Research. 2015. DOI: 10.1007/s11053-015-9277-9. $11 \mathrm{p}$.

55. Sedunova A.P., Veksler I.V, Zhdanov V, Kazymov K. P., Reid D. Chemical and textural variations across the UG2 chromitite at the Khuseleka mine, Bushveld Complex // Goldschmidt 2015.

\section{Mineralogical and Geochemical Investigations in the Perm State University (1916 - 2016)}

\section{R.G. Iblaminov}

Perm State University, 15 Bukireva Str., Perm 614990, Russia

E-mail: riaminov@psu.ru

The history of foundation and development of mineralogical and geochemical sciences on the Mineralogy and Petrography Department of the Perm State University for 100 years is presented. The achievements in the alluvial mineralogy and nanomineralogy are characterised. Relationship of development in the area of geochemical research on early stage with the European scientific school is discussed. The next stage is characterized by transition to investigations of trace elements and usage of the modern analytic base for environmental geochemistry. Petrographic and lithologic investigations have become the base for paleotectonic reconstruction of the Western Urals area. The study of distribution of mineral resources has been conducted on the base of specific minerageodynamic concept. The principles of minerageodinamic investigation of oil and gas basins, and methodology of reservoir study using modern technology were developed. The contribution of individual scientists in development in different scientific areas is illustrated.

Key worlds: history of sciences, nanomineralogy, geochemistry, petrography, lithology, economic geology, minerageodynamics, ecogeology, oil and gas geology.

\section{References}

1. Ablizin B.D., Klygina M.L., Kurbatskaya F.A., Kurbatskiy A.M. 1982.Verkhniy rifey i vend zapadnogo sklona Srednego Urala [Upper
Rifean and Vendian of the west slope of the Middle Urals]. Nauka, Moskva, p.140. (in Russian)

2. Abramovich J.M. 1956. Formy nakhozhdenia redkikh elementov $\mathrm{v}$ zemnoy kore [Occur- 
rence forms of rare elements in the Earth crust]. Uchenye zapiski Permskogo gosuniversiteta. 10(2): 179-184. (in Russian)

3. Aleksandrov V.V., Ignatyev N.A., Kobyak G.G. 1941. Volkonskoit Prikamya [Volkonsloite of Prikamye]. Uchen. zap. Molotov. univ. 4(3): 77. (in Russian)

4. Blinov S.M., Vaganov S.S., Veksler I.V., Ergaliev R.T., Zhdakaev V.I., Zolotaryov L.R., Iblaminov R.G., Isaeva G.A., Kazymov K.P., Krutik I.A., Mankova T.V., Menshikova E.A., Osovetskiy B.M., Perevozchikov B.V., Pishiotta A., Sedunova A.P., Suslov S.B. 2015. Mineralno-syryevaya baza Permskogo kraya dlya proizvodstva bazaltovogo volokna [Mineral resources of the Perm region for basalt fiber production]. $E d$. R.G. Iblaminov. PSU, Perm, p. 369. (in Russian)

5. Voskresenskiy V.K. 1940. K mineralogii medistykh peschanikov [Mineralogy of copper sandstone]. Uchen. zap. Permskogo gos. univ. 3(3): 73-78. (in Russian)

6. Goldshmidt V.M. 1937. Tri doklada po geokhimii [Three lectures on geochemistry]. Uchenye zapiski Permskogo univ., Annex to the 2: 42. (in Russian)

7. Iblaminov R.G., Kropachev A.M., Ablizin B.D. 1973. Geokhimiya malykh (aktsessornykh) elementov donnykh otlozheniy melkikh rechek Severnogo Urala [Geochemistry of sediments of the small (accessory) elements of small rivers from the Northern Urals]. In Allyuviy. Perm, 266(2): 40-45. (in Russian)

8. Iblaminov R.G., Lebedev G.V. 1989. Instruktsiya po geologicheskomu obsluzhivaniyu gornodobyvayushchikh predpriyatiy Nizhnetagilskogo metallurgicheskogo kombinata [Instruction on geological services for mining enterprises of the Nizhny Tagil Metallurgical Plant]. Permskiy univ., Perm, p. 181. (in Russian)

9. Iblaminov R.G., Lebedev G.V. 1995. Geologiya i poleznye iskopaemye Komi-Permyatskogo avtonomnogo okruga [Geology and mineral resources of the Komi-Perm Autonomous District]. Komi-Permyatskoe kn. izd-vo, Kudymkar, p. 136. (in Russian).

10. Iblaminov R.G. 2001. Osnovy minerageodinamiki [Basics of Minerageodynamics]. Izd. Permskogo univ., Perm, p.220. (in Russian)

11. Iblaminov R.G. 2004. Ekonomika mineralnogo syrya: Ucheb. Posobie [Economics of mineral raw materials: Textbook]. Perm, Perm. univ., p. 308. (in Russian)
12. Iblaminov R.G., Lebedev R.G. 2006. Vulkanicheskie kompleksy magmaticheskikh formatsiy zapadnogo sklona Srednego i Severnogo Urala [Volcanic complexes of magmatic formations of the western slope of the Central and Northern Urals]. Litosfera. 1: 76-90. (in Russian)

13. Iblaminov R.G. 2007. Osnovy geologii i geokhimii nefti i gaza: ucheb. posobie [Fundamentals of geology and geochemistry of oil and gas: Textbook]. Perm, Perm. univ., p. 256. (in Russian)

14. Iblaminov R.G. 2015. Minerageniya (osnovy minerageodinamiki): Ucheb. posobie [Minerageny: basics of minerageodynamics]. Perm, Perm. univ., p. 322. (in Russian)

15. Ignatyev N.A. 1936. Kersantitovye dayki iz shakhty Artem Vlasovskogo rudnika Donetskogo basseyna [Kersantite dikes in the Artem Vlasov mine of Donets Basin]. Uchen. zap. Perm. univ., 2(3): 237-259. (in Russian)

16. Ignatyev N.A. 1947. Geologo-petrograficheskiy ocherk Pulongskikh ozer v KareloFinskoy SSR [Geological and petrographic essay of Pulongskie Lakes in the KarelianFinnish SSR]. Uchen. zap. Perm. univ. 4(4): 123-140. (in Russian)

17. Ignatyev N.A. 1952. Rudy mednykh mestorozhdeniy Nyazepetrovskogo rayona [Ores of copper deposits of Nyazepetrovsk area]. Uchen. zap. Molotov. univ. 7(1): 39-55. (in Russian)

18. Ignatyev N.A. 1952. Spility Nyazepetrovskogo rayona [Spilites of Nyazepetrovsk area]. Uchen. zap. Molotov. univ. 7(1): 6167. (in Russian)

19. Kropachev A.M. 1964. Geokhimicheskoe unasledovanie nizhnepermskikh morskikh basseynov Preduralskogo progiba [Geochemical inheritance of Lower Permian marine basins of the Pre-Ural Foredeep]. Dokl. AN SSSR. 159(1): 111-113. (in Russian)

20. Kropachev A.M. 1973. Faktory migratsii i osazhdeniya malykh (aktsessornykh) elementov $\mathrm{v}$ zone gipergeneza [Migration and deposition factors of small (accessory) elements in the supergene zone]. Perm, p. 155. (in Russian)

21. Kropachev A.M., Kornev O.S., Iblaminov R.G. 1978. Opyt issledovaniya formy nakhozhdeniya malykh elementov v sovremennykh morskikh osadkakh [Previous finding form studies of minor elements in modern marine sediments]. In Kompleksnoe primenenie geologicheskih metodov issledovaniya 
morskogo dna. YUzhno-Sahalinsk, pp. 5763. (in Russian)

22. Kropachev A.M. 1983. Geneticheskaya informatsiya na urovne mineralov $\mathrm{v}$ oreolah rasseyaniya uglevodorodnyh zalezhey [Genetic information in the mineral level in the dispersion halos of hydrocarbon deposits]. In Novye idei $\mathrm{v}$ geneticheskoy mineralogii. Leningrad, pp. 87-89. (in Russian)

23. Kropachev A.M. 1983. Geohimicheskie bar'ery litogeneza i formirovanie mestorozhdeniy poleznyh iskopaemyh [Geochemical Lithogenesis barriers and the formation of mineral deposits]. PGU. Perm, p. 97. Dep. to VINITI 18 apr. 1983, № 2014. (in Russian)

24. Kropachev A.M. 2005. Ekologicheskaya geohimiya: polozhenie $\mathrm{v}$ sisteme estestvennyh nauk [Ecological Geochemistry: the location in the system of natural sciences]. In Ekologiya fundamentalnaya i prikladnaya: Problemy urbanizatsii. Materialy Mezhdunar. nauch.-prakt. konf. Ekaterinburg, p. 170. (in Russian)

25. Kurbatskaya F.A., Rybalchenko T.M., Savchenko S.V. 2001. Atlas mikrofotografiy terrigennyh i eksplozivno-injektsionnyh porod zapadnogo sklona Severnogo i Srednego Urala [Atlas micrographs of clastic and explosive-injecting rocks on the western slope of the Northern and Middle Ural]. p. 124. (in Russian)

26. Lebedev G.V., Iblaminov R.G., Iblaminova N.F. 2004. Regionalnaya mineragenicheskaya baza dannyh kak avtomatizirovannoe rabochee mesto geologa (ARMG) [Regional mineragenic database as a geologist's workstation (GWS)]. In Prikladnaya geohimiya: sb. st. Komputernye tekhnologii, Moskva, 5: 401-413. (in Russian)

27. Litvinov A.YA. 1970. Skarnirovanie i amfibolizatsiya vo vmeshchayushchey tolshche Olenegorskogo mestorozhdeniya zhelezistyh kvartsitov [Skarnification and amphibolization in the country rocks of Olenegorsk ferruginous quartzite deposit]. Sov. geologiya. 5: 55-68. (in Russian)

28. Lunev B.S., Kropachev A.M. 1959. Mestorozhdeniya graviya, peska $\mathrm{i}$ glin $\mathrm{v}$ Permskoy oblasti [Deposits of gravel, sand and clay in the Perm region]. Kn. izd., Perm, p. 148. (in Russian)

29. Morozov G.G., Osovetskiy B.M., Nakaryakova I.R., Rybal'chenko A.YA, SHafranovskiy YU.I., Kurbatskaya F.A., Kazymov K.P., Ilaltdinov I.YA. 2006. Pervye nahodki almazov na territorii platformennoy chasti Permskogo kraya [The first discoveries of diamonds in the territory of the platform part of the Perm region]. In Geologiya i poleznye iskopaemye Zapadnogo Urala. Perm, pp. 6-8. (in Russian)

30. Osovetskiy B.M. 1986. Tyazhelaya fraktsiya allyuviya [Heavy fraction of alluvium]. Izdvo Irkut. un-ta, Irkutsk, p. 259. (in Russian)

31. Osovetskiy B.M. 1992. Padenie mineralov v tyazhelyh zhidkostyah: Novye metody issled [Falling of minerals in heavy liquids: New methods of research]. Izd-vo Irkutsk. un-ta, Irkutsk, p. 138. (in Russian)

32. Osovetskiy B.M. 1993. Drobnaya granulometriya allyuviya [Fractional granulometry of alluvium]. Perm. un-t, Perm, p. 343. (in Russian)

33. Osovetskiy B.M. 2001. Tipohimizm shlihovyh mineralov: spravochnik [typochemistry of schlich minerals: reference book]. Perm. un-t, Perm, p. 244. (in Russian)

34. Osovetskiy B.M. 2004. Mineralogiya mezokaynozoya Prikam'ya. Izbrannye trudy [Mineralogy of Meso-Cenozoic of Kama region. Selected works]. Izd-vo PGU, PSI, PSSGK, Perm, p. 292. (in Russian)

35. Osovetskiy B.M., Menshikova E.A. 2006. Prirodno-tekhnogennye osadki [Natural and technogenic sediments]. Izd-vo Perm. un-ta, Perm, p.208. (in Russian)

36. Osovetskiy B.M., Kazymov K.P., Buntin Suvannudom. 2011. Morfologiya i himizm kassiterita iz elyuvial'noy rossypi rudnogo polya Boneng (LNDR) [The morphology and chemistry of the eluvial placers of cassiterite ore field Boneng (Lao PDR)]. In Problemy mineralogii, petrografii i metallogenii. Nauchnye chteniya pamyati P. N. CHirvinskogo. Perm. 14: 76-88. (in Russian)

37. Osovetskiy B.M. 2012. Nanoskulptura poverhnosti zolota [Nano sculpture of gold surface]. Permskiy un-t, Perm, p. 231. (in Russian)

38. Osovetskiy B.M., Moloshtanova N.E. 2012. Litologiya (klassifikatsiya, metody issledovaniya, opisanie osadochnyh porod): ucheb. Posobie [Lithology (classification, methods of research, description of sedimentary rocks): Studybook]. Permskiy un-t, Perm, p. 158. (in Russian)

39. Parfenova YU.V. 2010. Neftegazopromyslovaya geologiya: ucheb. posobie dlya studentov [Oil and gas geology: Studybook for 
students]. Ed. R.G. Iblaminov. Permskiy unt, Perm, p. 273. (in Russian)

40. Permskiy gosudarstvennyy universitet imeni A.M. Gorkogo: istoricheskiy ocherk 1916 1966 [Perm State University named after AM Gorky: historical essay 1916 - 1966]. Permskoe kn. izd., Perm, 1966. p. 294. (in Russian)

41. Polkanov A.A. 1918. Predvaritelny otchet o geologicheskih issledovaniyah vdol Murmanskoy zheleznoy dorogi na uchastke ot goroda Murmanska do stantsii Olenya [Preliminary report on geological studies along the Murmansk railway line in the area from the city of Murmansk to Olenya station]. In Izv. Geol. komiteta. 37(7-8): 589-599. (in Russian)

42. Starkov N.P. 1960. Kirsinskie otbelivayushchie gliny [Kirsinsky bleaching clay]. In Ekspress-informatsii TSBTI Perm. sovnarhoza. Khim. promyshlennost. 22: 1-4. (in Russian)

43. Starkov N.P., Fon-der-Flaass G.S. 1966. Formy zeren aktsessornogo tsirkona $\mathrm{v}$ porodah kristallicheskogo fundamenta vostoka Russkoy platformy [Forms of accessory zircon grains in the rocks of the crystalline basement of the east of the Russian Platform]. In Genezis mineralnyh individov $\mathrm{i}$ agregatov, ontogeniya mineralov. Moskva, pp. 284-290. (in Russian)

44. Starkov N.P. 1973. Mineralogiya pikritov zapadnogo sklona Urala [Mineralogy of picrites of the western slope of the Urals]. In Problemy petrologii Urala. Tr. Instit. geol. i geokh. UNTS AN SSSR. Sverdlovsk. 100: 53-69. (in Russian)

45. Starkov N.P., Fominyh V.G., Zilberman A.M. 1973. Diabazovye i gabbrodiabazovye formatsii zapadnogo sklona Urala [Diabase and gabbro diabase formation of the western slope of the Urals]. In Petrologiya i metallogeniya bazitov. Nauka, Moskva, pp. 166168. (in Russian)

46. Teterina N.N., Aliferova S.N., Appolonov V.N., Moloshtanova N.E. 2005. Vliyanie nesolyanyh mineralov na tekhnologicheskie svoystva rudy i produkty obogashcheniya Verhnekamskogo mestorozhdeniya soley [Influence of non-salty minerals on the technological properties of ore and products salt enrichment of Verkhnekamskoye deposit]. In Obogashchenie rud. 1: 16-19. (in Russian)

47. Tokarev V.A., Simonov A.I. 1936. K materialam po petrografii chetvertichnyh otlozheniy Permskogo rayona (V.-Mullinskie peski)
[The materials on the petrography of the Perm region of Quaternary sediments (V.Mullinskie Sands)]. Uchen. zap. Permskogo gos. univ. 2(2): 17-36. (in Russian)

48. Chadaev M.S., Iblaminov R.G., Gershanok L.A., Gershanok V.A., Prostolupov G.V. 2011. Geologicheskie struktury zapadnogo sklona Severnogo i Srednego Urala po dannym gravimetrii i magnitometrii [The geological structure of the western slope of the Northern and Middle Ural according to gravity and magnetic researching data]. Litosfera. 6: 134-140. (in Russian)

49. Chirvinskiy P.N. 1946. Klarki magmaticheskih porod shchitov i geosinklinaley. [Clarkes of igneous rocks shields and geosynclines]. In Akademiku D.S. Belyankinu $\mathrm{k}$ semidesyatiletiyu so dnya rozhdeniya i sorokapyatiletiyu nauchnoy deyatelnosti.. AN SSSR, Moskva-Leningrad, pp. 178-183. (in Russian)

50. Chirvinskiy P.N. 1948. Ionnye i atomnye konstanty psevdoelementov [Ion and atomic constants of pseudo elements]. Uch. zap. Perm. gos. univ. 4(4): 165-179. (in Russian)

51. Chirvinskiy P.N. 1949. Pallasity, ikh kolichestvennyy khimiko-mineralogicheskiy sostav i kolichestvennaya rol sredi drugikh grupp meteoritov [Pallasites, their quantitative chemical and mineralogical composition and quantitative role among other groups of meteorites]. In Meteoritika. Ed. V.G. Fesenkova. AN SSSR, Moskva-Leningrad. 6: 54-63. (in Russian)

52. Chirvinskiy P.N. 1953. Sredniy khimicheskiy sostav glavnykh mineralov izverzhennykh, metamorficheskikh i osadochnykh porod [Average chemical composition of major minerals of igneous, metamorphic and sedimentary rocks]. Harkov Univ., p. 96. (in Russian)

53. Osovetskiy B.M. 2004. Geochemistry of fluvial sediment heavy fraction. In Geochemistry 2004: 6th International Conference of Geochemistry: Alexandria pp. 155-156. (in Russian)

54. Osovetsky B.M. 2015. Aggregation of Nanogold Particles in the Environment In Natural Resources Research. DOI: 10.1007/s11053-015-9277-9. $11 \mathrm{p}$.

55. Sedunova A.P., Veksler I.V, Zhdanov V, Kazymov K. P., Reid D. 2015. Chemical and textural variations across the UG2 chromitite at the Khuseleka mine, Bushveld Complex In Goldschmidt. 